Beata Krawczyk-Brytka

Politechnika Gdańska, Polska - Gdansk University of Technology, Poland

Katarzyna StanKIEWICZ

Politechnika Gdańska, Polska - Gdansk University of Technology, Poland

PAWEt ZIEMIAŃSKI

Politechnika Gdańska, Polska - Gdansk University of Technology, Poland

Mıchat T. TOMCZAK

Politechnika Gdańska, Polska - Gdansk University of Technology, Poland

\title{
Efektuacyjność modelu mentalnego przedsiębiorczości
}

\section{Congruence of Mental Model of Entrepreneurship with Principles of Effectuation}

Streszczenie: Artykuł prezentuje dwa modele przedsiębiorczości: tradycyjny (kauzalny) i efektuacyjny. Zgodnie z modelem kauzalnym najważniejszymi czynnikami wpływającymi na sukces firmy są strategiczne planowanie i konkurencyjność. W modelu efektuacyjnym ważne są posiadane przez przedsiębiorcę zasoby, elastyczne reagowanie na szanse pojawiające się w otoczeniu i budowanie relacji biznesowych. Celem artykułu stała się ocena efektuacyjności mentalnego modelu przedsiębiorczości, czyli ocena, czy i w jakim stopniu model prezentowany przez badanych studentów jest koherentny $\mathrm{z}$ efektuacyjnym modelem przedsiębiorczości. W przeprowadzonych badaniach nacisk położono na cztery elementy modelu mentalnego przedsiębiorczości: opracowanie strategii, wykorzystanie zasobów, postawy wobec ryzyka i budowanie relacji. Wykorzystano 39-itemowy kwestionariusz, w którym proszono studentów o ocenę, jak bardzo dane stwierdzenia odnoszą się do efektywnego przedsięwzięcia biznesowego. Wyniki wskazują, że modele mentalne studentów odpowiadają założeniom modelu tradycyjnego. Jedynie w odniesieniu do planowania strategii integrują one elementy obu modeli. Zidentyfikowano różnice w modelach mentalnych przedsiębiorczości kobiet i mężczyzn. Wyniki badań posłużyły do opracowania rekomendacji dla kształtowania efektuacyjnych postaw przedsiębiorczych studentów, szczególnie w zakresie koopetycji, traktowania ryzyka jako hamulca bezpieczeństwa i koncentrowania się na posiadanych zasobach.

Abstract: The article presents two models of entrepreneurship: the traditional (causal) and the effectuation model. In the causal model, strategic planning and competitiveness are considered to be crucial for the venture's success. In the effectuation model the basis for success is the use of available resources, flexible response to emerging opportunities and building relationships. The aim of the article is to assess the congruence of the mental model of entrepreneurship held by students with the effectuation model. In the conducted research the emphasis was placed on four elements of the mental model: company's strategy, utilisation of its resources, attitude to risk and attitude to other entities operating on the market. A questionnaire containing 39 items referring to the above-mentioned aspects was used. Participants assessed the extent to which those items described an effective business enterprise. The results indicate that students' mental model is more congruent with the causal approach. The only aspect that integrates 
certain elements of causal, as well as effectual assumptions, is company's strategy. Some differences in man and woman mental model were discovered. Results of the research were used to develop recommendations for shaping entrepreneurial attitudes which include: the need to develop effectual approach in Polish students' entrepreneurial education, especially in the area of effectual coopetition, treating risk as a safety brake and focusing on possessed resources.

Słowa kluczowe: efektuacja; kauzalność; model mentalny; model mentalny przedsiębiorczości; przedsiębiorczość

Keywords: causation; effectuation; entrepreneurship; mental model; mental model of entrepreneurship

Otrzymano: 5 maja 2019

Received: 5 May 2019

Zaakceptowano: 12 sierpnia 2019

Accepted: 12 August 2019

Sugerowana cytacja/Suggested citation:

Krawczyk-Bryłka, B., Stankiewicz, K., Ziemiański, P., Tomczak, M.T. (2019). Efektuacyjność modelu mentalnego przedsiębiorczości, Przedsiębiorczość - Edukacja [Entrepreneurship - Education], 15(2), 59-69. doi: 10.24917/20833296.152.4.

\section{Wstęp}

Dominującą koncepcją wykorzystywaną w dotychczasowych badaniach dotyczących zachowań przedsiębiorczych i przedsiębiorczości była tradycyjna koncepcja przyczynowa (kauzalna). Stosunkowo nowa koncepcja efektuacyjnego podejścia do przedsiębiorczości (Sarasvathy, 2001), która w literaturze światowej zyskała już duże zainteresowanie badaczy, nadal jest dość słabo rozpowszechniona w Polsce (Kurczewska, 2012: 20-24). Dzieje się tak pomimo faktu, że podejście to wydaje się szczególnie wartościowe w obecnych, niezwykle dynamicznie zmieniających się uwarunkowaniach biznesu. Wskazują na to niektóre doniesienia literaturowe odnoszące się do innowacyjności i kreatywności działań przedsiębiorczych (Cieślik, Skala, 2016: 309-322), czy wczesnej internacjonalizacji (born global) małych i średnich przedsiębiorstw (Duliniec, 2017: 83-89). Stanowczo podkreśla się także konieczność wykorzystywania tej koncepcji w edukacji i przygotowaniu przyszłych przedsiębiorców (Mäkimurto-Koivumaa, Puhakka, 2013: 68-83).

Celem prezentowanych $\mathrm{w}$ artykule badań była ocena efektuacyjności mentalnego modelu przedsiębiorczości, czyli ocena czy, i w jakim stopniu model mentalny przedsiębiorczości prezentowany przez badanych studentów jest koherentny z efektuacyjnym modelem przedsiębiorczości. Artykuł jest kontynuacją pierwszego etapu badań, w którym wskazano poznawcze i behawioralne wskaźniki efektuacyjnego i kauzalnego modelu mentalnego przedsiębiorczości, wykorzystane w przeprowadzonych w powyższym celu badaniach.

\section{Mentalne modele przedsiębiorczości}

Modele mentalne definiowane są jako „poznawcze reprezentacje słowno-obrazowe [...] powstające $\mathrm{w}$ toku procesu myślenia lub rozumowania jako sposób na przedstawienie sobie w umyśle istoty problemu, a zwłaszcza składających się nań zależności” (Nęcka, 
Orzechowski, Szymura, 2006: 640). Reprezentacje takie nie tylko pozwalają wyjaśniać i rozumieć istotę zjawisk i idei, których dotyczą, ale także wpływają na percepcję, procesy przetwarzania informacji, sposób rozwiazywania problemów, ocenianie, uczenie się i podejmowanie decyzji (Gary, Wood, 2016), a przez to na sposób działania podmiotu (Spicer, 1998).

Analogicznie do powyższych definicji modele mentalne tworzone i wykorzystywane przez przedsiębiorców oraz menadżerów w trakcie ich zawodowej aktywności (mentalne modele przedsiębiorczości) rozumiane są jako uproszczone struktury wiedzy lub poznawcze reprezentacje dotyczące funkcjonowania środowiska biznesowego (Gary, Wood, 2011), będące kluczowymi determinantami wyboru strategii działania, podejmowania decyzji i osiągania sukcesu biznesowego (Gary, Wood, Pillinger, 2012).

W dotychczasowym, klasycznym podejściu przedsiębiorczość rozumiana była jako proces, w którym przedsiębiorca w pełni intencjonalnie i planowo identyfikuje i racjonalnie ocenia szanse realizacji swojego pomysłu, szacuje i pozyskuje niezbędne do tego zasoby, a w konsekwencji - wdraża i nadzoruje dążenie do wyznaczonego wcześniej celu (Glinka, Gutkowa, 2011; Shane, Venkataraman, 2000). Działania, które należy podjąć $\mathrm{w}$ tym procesie, wynikają z dokładnej, logicznej, przyczynowo-skutkowej (kauzalnej) analizy rynku i informacji z niego napływających (Fisher, 2012).

W kontraście do tego podejścia Sarasvathy $(2001,2008)$ zaproponowała koncepcję efektuacji, w której przedsiębiorca opiera się na subiektywnie kreowanych przez siebie obszarach możliwego działania, biorąc pod uwagę tylko zasoby w danym momencie posiadane i możliwe do wykorzystania. Na ich podstawie wyznacza cele, które chce i może osiągnąć. Przy czym w zależności od napływających informacji i/lub pojawiających się możliwości oraz nieprzewidzianych wcześniej okoliczności cele te są na bieżąco kształtowane i modyfikowane (Sarasvathy, 2008; Sarasvathy, Dew, 2005).

Specyfikę efektuacyjnego podejścia do przedsiębiorczości Sarasvathy przedstawiła jako pięć podstawowych zasad. Są to:

- zasada „wróbel w garści...” (bird-in-hand), polegająca na koncentrowaniu się na posiadanych w danym momencie zasobach, w tym na własnej wiedzy, umiejętności, zdolności i jak najlepszym ich wykorzystaniu przez tworzenie czegoś nowego zamiast poszukiwania i nabywania zasobów koniecznych do osiągnięcia konkretnego, wcześniej zaplanowanego celu,

- zasada "dopuszczalnej straty” (affordable loss), polegająca na określeniu największej dopuszczalnej straty, którą przedsiębiorca jest gotowy ponieść, zamiast kalkulacji i koncentracji na ocenie poziomu zwrotu inwestycji i zysku,

- zasada „Zwariowanego patchworku” (crazy quilit), polegająca na otwartości i nastawieniu na współdziałanie i współpracę z innymi stronami zainteresowanymi projektem, zamiast konkurowaniu $\mathrm{z}$ nimi,

- zasada „lemoniady” (when lifes gives you lemons, make lemonade), polegająca na postrzeganiu i wykorzystywaniu nieoczekiwanych i niespodziewanych sytuacji jako szans na inne, nowe działanie,

- zasada „pilota w samolocie” (pilot-in-the-plane), polegająca na proaktywnym podejściu do napotykanych szans, przejmowaniu sterów we własne ręce, zamiast koncentrowaniu się na trendach czy przewidywaniu przyszłości.

Wykorzystywanie tych zasad w praktyce pozwala nie tylko na stworzenie sieci zainteresowanych współdziałaniem podmiotów multiplikujących posiadane zasoby, lecz także na konwergencję celów współpracujących podmiotów (Sarasvathy i in., 2014: 71-93). 
Najczęstszym metaforycznym zobrazowaniem obu tych podejść, wykorzystywanym w literaturze, jest przykład kucharza, który reprezentując podejście przyczynowe, najpierw by decydował o tym, jaką potrawę przygotować (cel), aby następnie poszukiwać, gromadzić, nabywać produkty (zasoby) konieczne do podjęcia próby osiągnięcia zamierzonego celu. W przypadku podejścia efektuacyjnego metaforyczny kucharz - przedsiębiorca, rozpoczyna swoje działania od sprawdzenia, jakie produkty są $\mathrm{w}$ danym momencie w jego posiadaniu i biorąc pod uwagę czas, który może poświęcić, decyduje, jaką potrawę przygotuje (Sarasvathy, 2001).

Istnienie różnych podejść do przedsiębiorczości implikuje tym samym istnienie różnych modeli mentalnych, determinujących wybory w zakresie strategii działania, podejmowania decyzji i postrzegania sukcesu biznesowego, czyli różnych modeli mentalnych przedsiębiorczości. Wydaje się, że pod pewnymi względami efektuacyjny model przedsiębiorczości może obecnie przynosić korzyści w działaniach przedsiębiorczych, głównie ze względu na większą elastyczność tak potrzebną w nastawionym na innowacje i niezwykle dynamicznie zmieniającym się otoczeniu biznesowym.

\section{Badania własne}

Celem prezentowanych badań była ocena efektuacyjności mentalnego modelu przedsiębiorczości, czyli ocena, czy i w jakim stopniu model mentalny przedsiębiorczości prezentowany przez badanych studentów jest koherentny $z$ efektuacyjnym modelem przedsiębiorczości w zakresie ustalania strategii firmy, dysponowania jej zasobami, podejmowania ryzyka i budowania relacji z otoczeniem biznesowym. Powyższe kategorie odzwierciedlają realizację głównych pięciu zasad efektuacji.

Badanie przeprowadzono w grupie 124 studentów kierunku zarządzanie i analityka gospodarcza na Wydziale Zarządzania i Ekonomii Politechniki Gdańskiej, którzy w większości deklarowali zainteresowanie założeniem własnej działalności gospodarczej po zakończeniu studiów. Dodatkowo badanie przeprowadzone w grupie studentów pozwoliło na sformułowanie rekomendacji dotyczących kształtowania efektuacyjnych postaw przedsiębiorczych osób, które pozostają w procesie edukacyjnym.

Średnia wieku osób badanych wyniosła 21,6, najmłodszy uczestnik miał 19 lat, a najstarszy - 24 lata. 56\% badanych stanowiły kobiety, mężczyźni to pozostałe $44 \%$. Badanie miało formę kwestionariusza, w którym studentów poproszono o ocenę, na ile podane stwierdzenia opisują efektywnie działająca firmę. Odpowiedzi udzielano w pięciostopniowej skali, gdzie 1 oznaczało, że dane stwierdzenie nie pasuje do efektywnej firmy, zaś 5 oznaczało, że dane stwierdzenie bardzo dobrze pasuje do efektywnej firmy.

Lista stwierdzeń obejmowała zarówno określenia zgodne $\mathrm{z}$ tradycyjnym (18 stwierdzeń), jak i z efektuacyjnym modelem przedsiębiorczości (21 stwierdzeń), dotyczące różnych aspektów prowadzenia własnej działalności gospodarczej. Wyboru stwierdzeń dokonano na podstawie przeprowadzonej wcześniej analizy poznawczych i behawioralnych wskaźników modelu mentalnego przedsiębiorczości, którą zaprezentowano w artykule Modele mentalne przedsiębiorczości: wskaźniki efektuacyjne vs kauzalne (Krawczyk-Bryłka i in., 2018: 215-229). Stwierdzenia podzielono na kilka kategorii, wśród których znajdowały się omówione w tym artykule cztery dotyczące: strategii, zasobów, ryzyka i współpracy z otoczeniem. Dzięki temu, że wyniki przeprowadzonego badania wskazywały, jakie działania przedsiębiorców badani uważają za ważne dla efektywnego prowadzenia 
własnej firmy, czyli jak rozumieją i wyjaśniają istotę przedsiębiorczości, można było zidentyfikować ich model mentalny przedsiębiorczości.

Wyniki badań

Rycina 1 przedstawia opinie studentów dotyczące oceny efektywności działań przedsiębiorców zgodnych z modelem kauzalnym vs efektuacyjnym.

Przedstawiono średnie oceny efektywności dla poszczególnych obszarów działań przedsiębiorcy, funkcjonowania efektywnej firmy. Widoczna jest wyższa ocena działań właściwych dla modelu kauzalnego w odniesieniu do trzech z czterech badanych kategorii. Oznacza to, że mentalny model przedsiębiorczości osób badanych jest w większym stopniu zgodny z modelem kauzalnym niż efektuacyjnym. Największa różnica dotyczyła wyników z kategorii „podejmowanie ryzyka”, gdzie średnia zgodna z modelem kauzalnym wynosi 4,24 , natomiast średnia zgodna $\mathrm{z}$ modelem efektuacyjnym 3,81 . Analiza testem t-studenta wskazuje istotność statystyczną tej różnicy $(\mathrm{p}<0,0001, \mathrm{t}=-5,7)$, co oznacza, że badani studenci zdecydowanie silniej identyfikują się z tradycyjnym modelem przedsiębiorczości, w którym dokładnie analizuje się koszty i zyski przed dokonaniem wyboru najlepszego rozwiązania i ocenia ryzyko z punktu widzenia możliwych korzyści wynikających z jego podjęcia.

Model efektuacyjny, gdzie zgodnie z zasadą „dopuszczalnej straty” przedsiębiorcy ustalają graniczny poziom potencjalnych strat, który wyznacza zakres podejmowanego ryzyka i gdzie jest to proces ciągły, ma mniejsze znaczenie dla modelu mentalnego przedsiębiorczości badanej grupy. Warto zwrócić jednak uwagę, że poziomy średnich zarówno dla efektuacyjnych, jak i dla kauzalnych stwierdzeń pozostają dość wysokie, co oznacza, że elementy obu modeli mogą być obecne w modelu mentalnym przedsiębiorczości

Rycina 1. Ocena efektywności działań zgodnych z modelem kauzalnym vs efektuacyjnym w opinii studentów

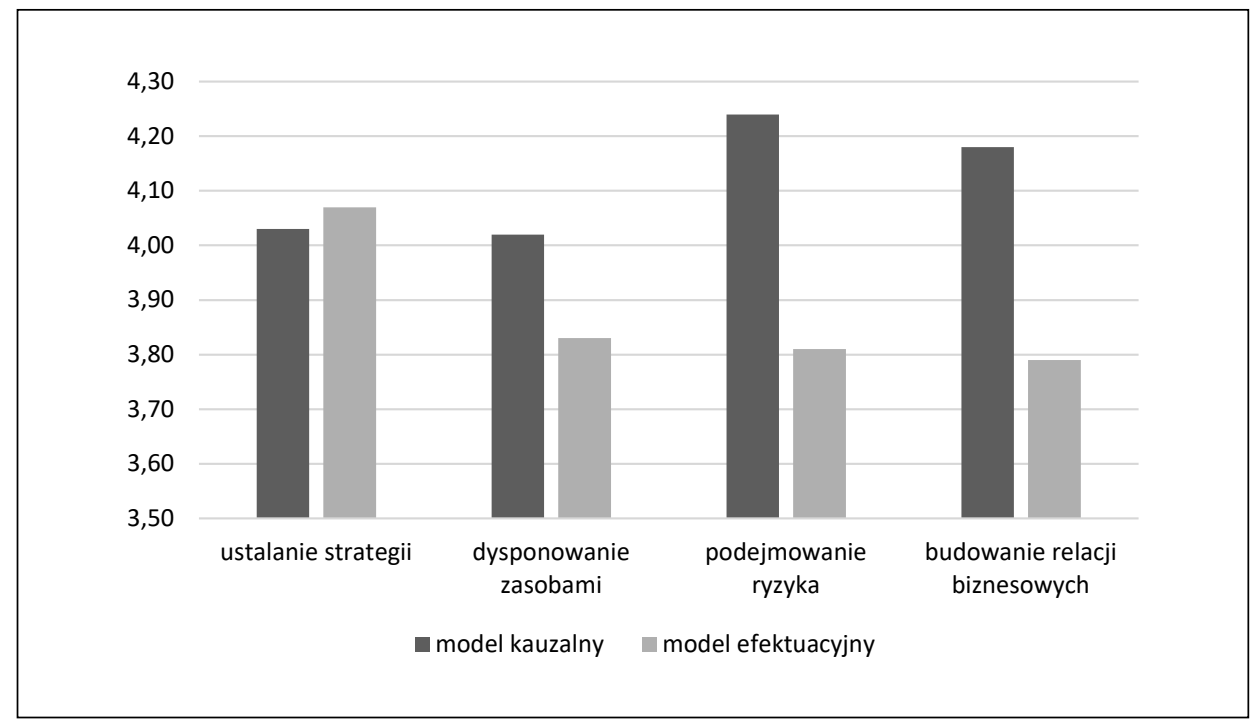

Źródło: opracowanie własne 
badanych respondentów. Dotyczy to również kategorii „dysponowanie zasobami” i „budowanie relacji z otoczeniem biznesowym", gdzie średnie dla modelu kauzalnego były istotnie wyższe. Studenci silniej identyfikowali prowadzenie efektywnej firmy przez przedsiębiorcę z kauzalnym modelem, czyli:

- uważali, że przedsiębiorca raczej szacuje i pozyskuje zasoby potrzebne do działania firmy (model kauzalny), niż wyznacza kierunki działania firmy na podstawie posiadanych i dostępnych zasobów (efektuacyjna zasada „wróbel w garści”) oraz

- byli bardziej przekonani, że przedsiębiorca musi analizować działania konkurencji, by z nią wygrywać i pozyskiwać użytecznych parterów biznesowych (model kauzalny), niż że na drodze do sukcesu firmy ważne jest aktywne budowanie wszelkich relacji, korzystanie z zalet szerokiego networkingu i wzajemne wspieranie się przedsiębiorców na rynku (zasada „szalonego patchworku”).

Zestawienie średnich oraz wartości testu t-studenta dla wszystkich badanych kategorii pokazano $\mathrm{w}$ tabeli 1. Jedynie w kategorii dotyczącej planowania strategii firmy wyniki dotyczące modelu tradycyjnego i efektuacyjnego nie różnią się istotnie statystycznie. Zarówno stwierdzenia koherentne z kauzalnym modelem, jak i z modelem efektuacyjnym uzyskały średnie na poziomie 4 . W zakresie tego pierwszego modelu badani szczególnie silnie identyfikowali się ze stwierdzeniami dotyczącymi konieczności rozpoczynania działań biznesowych od zaplanowania strategii i uwzględniania jej w priorytetyzowaniu podejmowanych działań.

Tabela 1. Analiza istotności statystycznej pomiędzy wynikami dotyczącymi kauzalnego (KAZ) i efektuacyjnego (EFE) modelu przedsiębiorczości

\begin{tabular}{|l|c|c|c|c|}
\hline \multicolumn{1}{|c|}{ Kategoria: } & $\begin{array}{c}\text { Średnia } \\
\text { EFE }\end{array}$ & $\begin{array}{c}\text { Średnia } \\
\text { KAZ }\end{array}$ & p & t \\
\hline Podejmowanie ryzyka & 3,81 & 4,24 & $<0,0001$ & $-5,7$ \\
\hline Dysponowanie zasobami & 3,83 & 4,02 & $<0,0001$ & $-4,7$ \\
\hline Budowanie relacji z otoczeniem & 3,79 & 4,18 & $<0,05$ & $-2,3$ \\
\hline Ustalanie strategii firmy & 4,07 & 4,03 & --- & -- \\
\hline
\end{tabular}

Źródło: opracowanie własne

Kontrolowanie wdrażania strategii w codziennych działaniach przedsiębiorcy, które jest również wpisane w model kauzalny, miało dla respondentów nieco mniejsze znaczenie. Z kolei w modelu efektuacyjnym silniejsze okazały się przekonania dotyczące konieczności analizowania sytuacji i dopasowywania do niej planów firmy niż, bardzo charakterystyczne dla efektuacji, płynność strategii i bieżące jej modyfikowanie.

Porównanie wyników uzyskanych przez kobiety i mężczyzn biorących udział w badaniu wykazało pewne potencjalne różnice pomiędzy modelami mentalnymi przedsiębiorczości obu tych grup. Dotyczą one dwóch kategorii:

- strategii firmy: odpowiedzi mężczyzn (M) są silniej koherentne z efektuacyjnymi elementami tej kategorii niż odpowiedzi kobiet $(\mathrm{K})$ - średnie odpowiednio: M: 4,23; $\mathrm{K}: 3,93 ; \mathrm{t}=2,19 ; \mathrm{p}<0,05$,

- budowania relacji z otoczeniem biznesowym: w męskim modelu mentalnym silniejsze jest kauzalne podejście, opierające się na konkurowaniu z innymi przedsiębiorcami i współpracy tylko z takimi partnerami, których wkład może przynieść korzyści dla firmy - średnie odpowiednio: $\mathrm{M}: 4,4 ; \mathrm{K}: 3,92 ; \mathrm{t}=3,05 ; \mathrm{p}<0,05$. 
Rycina 2. Porównanie modeli mentalnych przedsiębiorczości w zależności od płci

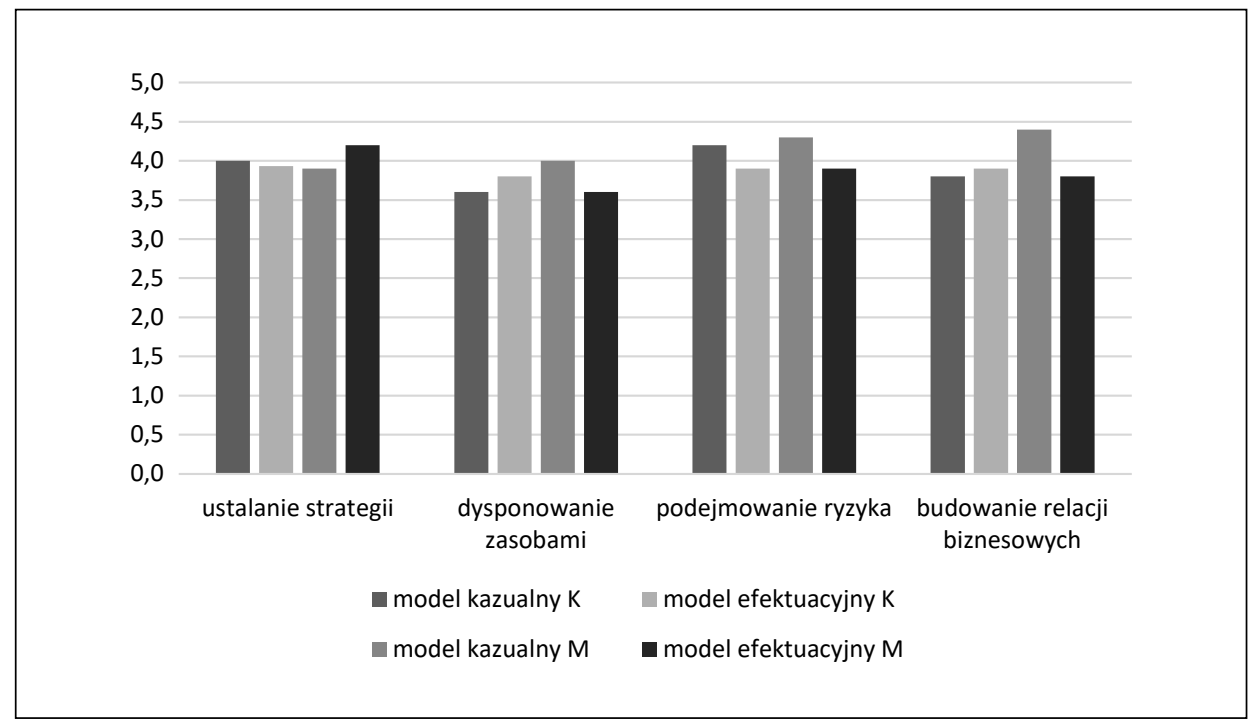

Źródło: opracowanie własne

Zauważalna (choć nieistotna statystycznie) jest też różnica dotycząca przekonań o sposobie dysponowania zasobami. Mężczyźni częściej wskazywali kauzalne działania jako charakterystyczne dla efektywnego przedsiębiorcy, w kobiecym modelu wyższe znaczenie mają czynniki efektuacyjne.

Szczegółowe porównanie wyników zależnie od płci respondentów pokazano na rycinie 2 . Widoczne jest, że w przeprowadzonym badaniu mężczyźni wyrażali zwykle bardziej zdecydowane opinie, opowiadając się za tradycyjnym rozumieniem przedsiębiorczości (oprócz omówionego wyżej podejścia do strategii firmy). Opinie kobiet są mniej stanowcze w ocenie znaczenia poszczególnych stwierdzeń dla efektywnej działalności przedsiębiorczej. Jedynie w wypadku podejścia do ryzyka kobiety wyrażają zdecydowanie większą akceptację dla kauzalnego modelu przedsiębiorczości.

\section{Wnioski i rekomendacje}

Przeprowadzone badanie pozwoliło na sformułowanie wniosków dotyczących dwóch obszarów:

1. oceny modelu mentalnego przedsiębiorczości w grupie badanych studentów,

2. rekomendacji z zakresu edukacji przedsiębiorczej skoncentrowanych na potrzebach tej grupy respondentów.

Otrzymane wyniki wskazują, że w badanej grupie dominował tradycyjny model mentalny przedsiębiorczości, a koherencja modeli mentalnych studentów z zasadami efektuacyjności była na dość niskim poziomie. Jedynie w myśleniu o strategii firmy widoczna była otwartość na elastyczne, efektuacyjne podejście, dopasowywanie strategii i planów do zmieniających się warunków otoczenia. Tylko w tym obszarze działania model mentalny przedsiębiorczości w badanej grupie można uznać za hybrydowy, czyli integrujący zarówno założenia kauzalnego, jak i efektuacyjnego modelu przedsiębiorczości. Różnice 
zidentyfikowane pomiędzy kobietami a mężczyznami sugerują, że płeć może być ważnym czynnikiem determinującym typ modelu mentalnego przedsiębiorczości.

Ograniczeniem interpretacji przeprowadzonych badań jest zasięg badanej grupy uzyskane wyniki nie mogą być odnoszone do całej populacji. Jednakże ważnym ich atutem jest podjęta próba identyfikacji elementów efektuacyjnego modelu przedsiębiorczości w modelach mentalnych młodego pokolenia przyszłych, potencjalnych przedsiębiorców. Jest to nowe podejście w zakresie badań postaw i zachowań przedsiębiorczych. Pozwala też postawić pytania, stanowiące wyzwanie dla kolejnych projektów badawczych, stymuluje do poszukiwania kolejnych czynników decydujących o koherencji modelu mentalnego z tradycyjnym lub efektuacyjnym modelem przedsiębiorczości.

Ważnym rezultatem podjętych badań jest też możliwość sformułowania kilku sugestii dotyczących edukacji przedsiębiorczej:

Widoczna jest potrzeba wzmacniania efektuacyjnego sposobu myślenia o relacjach pomiędzy uczestnikami rynku, uczenia współpracy, budowania synergii i odwagi w poszukiwaniu wsparcia w zamian za poleganie jedynie na własnych możliwościach.

Wskazane jest rozwijanie kompetencji związanych z budowaniem szerokich kontaktów w otoczeniu biznesowym i networkingu. Być może charakterystyka pokolenia $Y$ i Z umożliwia wykorzystywanie w tym obszarze dostępnych narzędzi, jakimi są media społecznościowe, tak często i dość naturalnie przez nich wykorzystywane.

Istnieje potrzeba promowania koopetycji, czyli jednoczesnego łączenia działań konkurencyjnych z kooperacyjnymi. Takie podejście, oparte na konkurowaniu z zasadą „szalonego patchworku” i „pilota w samolocie”, ma wiele zalet. Są wśród nich: wzajemne uczenie się partnerów, budowanie relacji opartych na zaufaniu i otwartej komunikacji, ułatwienie dostępu do komplementarnych zasobów i wzrost przewagi rynkowej.

Model efektuacyjny może inspirować do postrzegania ryzyka nie tylko jako wyzwania, które należy kalkulować, podejmując strategiczne decyzje (model kauzalny), ale również jako hamulec bezpieczeństwa, który chroni przed przekroczeniem granic opłacalności inwestycji, wyznacza zakres możliwych do poniesienia strat i sprawia, że podejmując wyzwania, przedsiębiorca nie naraża się na ostateczną porażkę.

Kształtowanie efektuacyjnego postrzegania zasobów firmy to nauka korzystania $\mathrm{z}$ tego, co się posiada, zamiast koncentrowania się na tym, czego brakuje. W tym przypadku model efektuacyjny uczy uważności i kreatywności w korzystaniu z nich dla celów biznesowych. Nie pozwala również traktować braku zasobów jako wymówki, bariery działań przedsiębiorczych lub usprawiedliwienia w sytuacji niepowodzenia.

Literatura

References

Cieślik, J., Skala, A. (2016). Nowe tendencje w kształceniu innowacyjnych przedsiębiorców. Horyzonty Wychowania, 34(15), 309-322.

Duliniec, E. (2017). Efektuacja, marketing przedsiębiorców i wczesna internacjonalizacja przedsiębiorstw. Marketing i Rynek, 9, 83-89.

Fisher, G. (2012). Effectuation, causation, and bricolage: A behavioural comparison of emerging theories in entrepreneurship research. Entrepreneurship Theory and Practice, 5(36), 1019-1051.

Gary, M.S., Wood, R.E. (2016). Unpacking mental models through laboratory experiments. System Dynamic Review, 2(32), 99-127. 
Gary, M.S., Wood, R.E. (2011). Mental models, decision rules, and performance heterogeneit. Strategic Management Journal, 6(32), 569-594.

Gary, M.S., Wood, R.E., Pillinger, T. (2012). Enhancing mental models, analogical transfer, and performance in strategic decision making. Strategic Management Journal, 11(33), 1229-1246.

Glinka, B., Gutkowa, S. (2011). Przedsiębiorczość. Warszawa: Oficyna Wolters Kluwer Business.

Krawczyk-Bryłka, B., Stankiewicz, K., Tomczak, M., Ziemiański, P. (2018). Modele mentalne przedsiębiorczości: wskaźniki efektuacyjne vs kauzalne. Przedsiębiorczość i Zarządzanie, vol. XIX, 10(II), 215-229.

Kurczewska, A. (2012). W jaki sposób myślą przedsiębiorcy?, czyli „Jeśli mogę kontrolować przyszłość, nie muszę jej przewidywać”. E-mentor, 5, 20-24.

Mäkimurto-Koivumaa, S., Puhakka, V. (2013). Effectuation and causation in entrepreneurship education. International Journal of Entrepreneurial Venturing, 1(5), 68-83.

Necka, E., Orzechowski, J., Szymura, B. (2006). Psychologia poznawcza. Warszawa: PWN.

Sarasvathy, S.D. (2001). Causation and effectuation: Toward a theoretical shift from economic inevitability to entrepreneurial contingency. Academy of Management Review, 2(26), 243-263.

Sarasvathy, S.D. (2008). Effectuation: Elements of entrepreneurial expertise. Edward Elgar Publishing.

Sarasvathy, S.D., Dew, N. (2005). New market creation through transformation. Journal of Evolutionary Economics, 5(15), 533-565.

Sarasvathy, S., Kumar, K., York, J.G., Bhagavatula, S. (2014). An effectual approach to international entrepreneurship: Overlaps, challenges, and provocative possibilities. Entrepreneurship Theory and Practice, 1(38), 71-93.

Shane, S., Venkataraman, S. (2000). The promise of entrepreneurship as a field of research. Academy of Management Review, 1(25), 217-226.

Spicer, D.P. (1998). Linking mental models and cognitive maps as an aid to organisational learning. Career Development International, 3(3), 125-132.

Beata Krawczyk-Bryłka, dr, Politechnika Gdańska, Wydział Zarządzania i Ekonomii. Psycholog, doktor nauk humanistycznych w dziedzinie zarządzania, adiunkt w Katedrze Przedsiębiorczości i Prawa Gospodarczego. Jej zainteresowania badawcze koncentrują się wokół zagadnień dotyczących zarządzania zespołami wirtualnymi, zarządzania zaufaniem w zespołach, psychologicznych aspektów przedsiębiorczości oraz zespołów przedsiębiorczych. Jest kierownikiem projektu NCN: „Efektuacyjny model zespołu przedsiębiorczego. Jak działają przedsiębiorcze zespoły odnoszące sukces”, Quality Lead filaru People management \& personal development na studiach MBA Politechniki Gdańskiej. W latach 2008-2012 była prodziekanem ds. kształcenia na Politechnice Gdańskiej. Jest członkiem Gdańskiego Towarzystwa Naukowego i Polskiego Stowarzyszenia Psychologii Organizacji.

Beata Krawczyk-Bryłka, PhD, Gdansk University of Technology, Faculty of Management and Economics. Psychologist, PhD in Management, assistant professor in the Department of Entrepreneurship and Business Law. She is interested in virtual team management, team trust management, psychological aspects of entrepreneurship and entrepreneurial teams. The leader of the project: "Effectuation model of entrepreneurial teams. How do effective entrepreneurial teams operate?" founded by NSC. Quality Lead of People Management \& Personal Development in International MBA GUT programme, in 2008-2012 Vice Dean for education. Member of The Scientific Society of Gdańsk and Polish Association of Organizational Psychology.

ORCID: 0000-0001-7677-9549

\section{Adres/Address:}

Politechnika Gdańska

Wydział Zarządzania i Ekonomii

ul. Narutowicza 11/12

80-233 Gdańsk

e-mail: beabrylk@pg.edu.pl 
Katarzyna Stankiewicz, dr, Politechnika Gdańska, Wydział Zarządzania i Ekonomii. Psycholog, dr nauk społecznych w dziedzinie psychologii. Jej zainteresowania badawcze koncentrują się wokół problematyki zarządzania zespołami zróżnicowanymi, psychologicznych uwarunkowań efektywności pracy zespołów i psychologicznych aspektów przedsiębiorczości.

Katarzyna Stankiewicz, PhD, Gdansk University of Technology, Faculty of Management and Economics. Psychologist, PhD in Psychology. Her research interests focus on diverse team management, psychological determinants of teamwork effectiveness and psychological aspects of entrepreneurship.

ORCID: 0000-0002-97807702

\section{Adres/Address:}

Politechnika Gdańska

Wydział Zarządzania i Ekonomii

ul. Narutowicza 11/12

80-233 Gdańsk, Polska

e-mail: katarzyna.stankiewicz@zie.pg.gda.pl

Michał T. Tomczak, dr nauk społecznych, Politechnika Gdańska, Wydział Zarządzania i Ekonomii. Jego zainteresowania badawcze koncentrują się wokół problematyki zarządzania zasobami ludzkimi, a w szczególności kompetencji pracowników oraz technologii wspomagających integrację osób ze spektrum zaburzeń autystycznych w cyfrowym środowisku pracy. Jest koordynatorem Zespołu ds. Monitorowania Losów Zawodowych absolwentów PG oraz kierownikiem Studiów Podyplomowych Menedżer HR oraz Zarządzanie Samorządem Terytorialnym. Kierownik i wykonawca w kilku projektach finansowanych z Narodowego Centrum Nauki oraz Narodowego Centrum Badań i Rozwoju. Autor artykułów w czasopismach naukowych, rozdziałów w monografiach, raportów z badań oraz podręcznika z zakresu zarządzania zasobami ludzkimi. Członek Gdańskiego Towarzystwa Naukowego oraz ekspert Narodowej Agencji Wymiany Akademickiej (NAWA).

Michał T. Tomczak, PhD in Social Sciences, Gdańsk University of Technology, Faculty of Management and Economics. His research interests focus on Human Resources Management, particularly on employees' competencies and Assistive Technologies integrating employees with Autism Spectrum Disorders within the digitalised workplace. Head of Research Team in the field of GUT Graduates Professional Situation Monitoring and head of HR Manager and Local Self-Government Management postgraduate programs. Project leader and researcher in several research projects financed by the National Science Centre and the National Centre for Research and Development. Author of articles in scientific journals, chapters in monographs, research reports and Human Resources Management Handbook for University Students. Member of the Scientific Society of Gdańsk and expert of Polish National Agency for Academic Exchange (NAWA).

ORCID: 0000-0002-2916-5015

\section{Adres/Address:}

Politechnika Gdańska

Wydział Zarządzania i Ekonomii

ul. Narutowicza 11/12

80-233 Gdańsk, Polska

e-mail: michal.tomczak@zie.pg.edu.pl

Paweł Ziemiański, dr, Politechnika Gdańska, Wydział Zarządzania i Ekonomii. Psycholog, doktor nauk społecznych w dziedzinie psychologii, adiunkt w Katedrze Przedsiębiorczości i Prawa Gospodarczego. Jego zainteresowania badawcze dotyczą przedsiębiorczych zespołów, przedsiębiorczego poczucia samoskuteczności oraz efektuacji jako sposobu podejmowania decyzji przez 
indywidualnych przedsiębiorców, a także tych, którzy działają w zespołach. Zajmuje się także psychologicznymi aspektami sprawowania władzy w organizacjach.

Paweł Ziemiański, PhD, Gdansk University of Technology, Faculty of Management and Economics. Psychologist, PhD in Psychology, assistant professor in the Department of Entrepreneurship and Business Law. His research interests include entrepreneurial teams, entrepreneurial self-efficacy and effectuation as a framework of decisions (made by individual entrepreneurs as well as those who operate in teams). He is also interested in psychological aspects of holding power in organisations.

ORCID: 0000-0002-4391-9282

\section{Adres/Address:}

Politechnika Gdańska

Wydział Zarządzania i Ekonomii

ul. Narutowicza 11/12

80-233 Gdańsk, Polska

e-mail: pawel.ziemianski@zie.pg.gda.pl

Artykuł powstał w ramach projektu badawczego: „Efektuacyjny model zespołu przedsiębiorczego. Jak działają przedsiębiorcze zespoły odnoszące sukces?", finansowanego przez NCN w ramach konkursu Opus 13 (UMO$-2017 / 25 / \mathrm{B} / \mathrm{HS} 4 / 01507)$. 